\title{
Komunikační písemnosti moravských panství Případová analýza na příkladu komunikace panství Trebíč, Uherský Brod, Veveří a Židlochovice na konci 18. a v první polovině 19 . století
}

Kateřina Kovárová / 362617@mail.muni.cz

Ústav pomocných věd historických a archivnictví, Filozofická fakulta, Masarykova univerzita

\begin{abstract}
The study is based on an analysis of the communication papers of selected manorial nobility administrations, mainly from the end of the 18th and the beginning of the 19th century, using four large Moravian estates Třebíč, Uherský Brod, Veveři and Židlochovice as examples. It is concerned with individual types of documents and the form of communication between the particular levels of instance administration.
\end{abstract}

\section{Keywords}

diplomatics, Moravia, written documents of manorial nobility administration, office, communication papers, end of the $18^{\text {th }}$ century, beginning of the $19^{\text {th }}$ century 
Posttereziánské období je typické svou tendencí ke sjednocování správy na všech úrovních. Jejím důsledkem měla přirozeně být i unifikace písemností užívaných ke komunikaci mezi jednotlivými úřady. Ve vrchnostenské správě se měly rozeznávat tři základní druhy písemností určených pro komunikaci, jimiž byly nařízení neboli výnosy, zprávy a nóty. ${ }^{1}$ Jako nařízení se označují všechny spisy posílané od nadřízených úřadů úřadům podřízeným. Patří mezi ně např. dekrety, rezoluce, příkazy nebo vyřízení. Korespondence opačným směrem se nazývá zprávy. Ty měly ustálenou vnější formu, kdy se psalo na přeložený arch papíru, obvykle na pravou stranu vytvořeného sloupce, aby levá zůstala volná pro vyjádření a poznámky nadřízeného úřadu, které byly často psány přímo na podání. Na vnější straně zprávy musela být adresa a rubrum, tedy označení úřadu, jemuž byla podávána, s krátkým obsahem podání. Odpovídalo-li se zprávou na nějaký výnos, uvádělo se jeho číslo. Nóty byly vyhrazeny pro komunikaci na stejné správní úrovni, v tomto případě tedy pro dopisování si s ostatními vrchními úředníky jiných panství nebo jimi mohly komunikovat mezi sebou jednotlivé úřady zastoupené ve správě panství, ale to nebylo zvykem. Tato komunikace probíhala obvykle přes vrchní úřad, ${ }^{2}$ probíhala-li písemně. Na rozdíl od zpráv nemusely nóty mít rubrum vůbec. ${ }^{3}$

Nabízí se otázka, zda a jak tento na první pohled jednoduchý model fungoval v praxi. Jako účelné se proto jeví zvolit metodu sondy do písemné komunikace vybraných velkostatků a na jejich př́kladu ukázat jednotlivé typy písemností a podobu komunikace mezi individuálními stupni instanční správy. Původní myšlenka, určit jako výchozí bod vrchní úřad panství, jakožto centrum, od kterého diplomatická produkce vycházela a zároveň k němu přicházela, se neukázala jako funkční řešení. Výzkum přinesl nutnost podívat se na písemnosti jednotlivých úřadů a institucí zvlášte, ač se mnohé z nich vzájemně podobají.

Pro potřeby této studie byly zvoleny velkostatky Třebíč, Veveří, Uherský Brod a Židlochovice se zaměřením na období konce 18. a první poloviny 19. století. Jejich výběr podléhal několika kritériím. Jako stěžejní se ukázala pramenná základna velkostatkových fondů a také to, že ve sledovaném období nenáležely jednomu majiteli. Vzhledem k jejich geografické vzdálenosti a poloze lze také předpokládat rozdíly v zaměření hospodářství. ${ }^{4}$

Panství Třebíč, Uherský Brod a Židlochovice patřila významným majitelům z řad šlechty. Ve sledovaném období se u Třebíče ani Uherského Brodu majitelé nezměnili, židlochovické panství majitele vystřídalo jedenkrát. ${ }^{5}$ Proti nim stojí panství Veveří, které

1 Janoušek, Emanuel - Hanzal, Josef: Patrimoniálni správa a její písemnosti po r. 1526. In: Česká diplomatika do r. 1848. Edd. Šebánek, Jindřich - Fiala, Zdeněk - Hledíková, Zdeňka. Praha 1984 2. vyd., s. 315.

2 Moravský zemský archiv v Brně (dále MZA Brno), F 219 Velkostatek Veveří, kart. 99, inv. č. 117.

3 Janoušek, E. - Hanzal, J.: Patrimoniálni správa, s. 316.

4 K rozdílům v hospodářském zaměření srovnej úvody inventářů př́slušných archivních fondů: Voldán, Vladimír - Bräuner, Vilém - Hamerníková, Anna: Velkostatek Židlochovice 1445-1918. Inventář. Brno 1962 , s. 6; Ježková, Marie - Štarha, Ivan: Velkostatek Třebič (1335) 1538-1949. Inventář. Brno 1961, s. 7; Obršlík, Jindřich: Velkostatek Veveři 1730-1937. Inventář. Brno 1963, s. 13; Balcárek, Pavel - Zaoralová, Marie: Velkostatek Uherský Brod (1351) 1580-1945, Brno 1977, s. 8.

5 Voldán,V. - Bräuer, V. - Hamerníková, A.: Velkostatek Židlochovice, s. 1. 
majitele různého postavení střídalo poměrně často. ${ }^{6} \mathrm{Na}$ všech panstvích byl zastoupený obvyklý úřednický aparát a všechna byla začleněna do systému ústřední správy jednoho majitele.

Další z úkolů, před které nás staví studium písemností vrchnostenské správy je ujasnění terminologie. Literatura opomíjí písemnosti používané pro komunikaci jako takové a zahrnuje je pod obecný název korespondence. ${ }^{7}$ Problémovým bodem jsou především písemnosti označené jako nóty. Obecně se jedná o písemné sdělení mezi úřady na stejné úrovni, ${ }^{8}$ avšak mezi diplomatickým materiálem, se kterým pracujeme, se objevují písemnosti př́mo takto nadepsané. ${ }^{9}$ Svou formou připomínají nóty na zeměpanské úrovni, tedy jednoduché písemnosti bez úvodních formalit nadepsané Note, ${ }^{10}$ které se používaly pro krátká sdělení úředního charakteru. ${ }^{11}$ Končí datací a podpisem odesílajícího úředníka. Toto označení je tedy do jisté míry zavádějící, pokud literatura hovoří o nadřazeném pojmu pro komunikační písemnosti na souřadné úrovni. Mezi úřady na vyšší úrovni se nóty objevují také, ${ }^{12}$ ale vždy sloužily pro rychlou komunikaci. Pro komunikaci mezi sebou na dvorské úrovni úřady používaly tzv. insuláty ${ }^{13}$ a zeměpanské úřady zase tzv. misivy rekvizitoriální. ${ }^{14}$

\section{Krajský úřad}

Se zavedením systému instanční správy se panství musely začít postupně správně zodpovídat krajským úřadům. Jejich vzájemná komunikace probíhala především formou různých hlášení, která muselo panství poskytovat, a zároveň od krajského úřadu přijímalo nařízení a rozkazy.

Korespondence pro krajský úřad se ve fondech zkoumaných velkostatků téměř nezachovala a je jí málo i ve fondech krajských úřadů. Jednalo se o německy psané zprávy a hlášení, klasicky na pravou stranu listu. Krajský úřad je ve všech př́ípadech shodně titulován jako Löbliches K. K. Kreisamt. Z vnější strany byla adresa a rubrum. Vrchní úřad takto posílal i žádosti jménem poddaných v záležitostech, které krajský úřad vyřizoval. ${ }^{15}$

6 Obršlík, J.: Velkostatek Veveři, s. 4-5.

7 Janoušek, E. - Hanzal, J.: Patrimoniální správa, s. 315.

8 Rameš, Václav: Slovnik pro historiky a návštěuníky archivui. Praha 2006, s. 179.

9 Např. MZA Brno, F 281 Velkostatek Uherský Brod, kart. 121, inv. č. 582, fol. 143.

10 Sviták, Zbyněk: Z počátků moderni byrokracie. Nejvyšší zeměpanský úřad na Moravě v letech 1748-1782. Vyd. 1. Brno 2011, s. 444.

11 Týž: Písemná komunikace správních instituci zeměpanského charakteru v 17. a 18. století (na př́kladu Moravy). In: Jakž lidé hodnověrní zprávu činí: formy písemné komunikace v raném novověku. Praha 2018, s. 65.

12 Tamtéž, s. 65, 71.

13 Hochedlinger, Michael: Aktenkunde: Urkunden- und Aktenlehre der Neuzeit. Wien - Oldenbourg, 2009, s. 216.

14 Sviták, Z.: Z počátki̊ moderni byrokracie, s. 432-435.

15 Např́íklad žádosti o prodloužení platnosti cestovních pasů pro Romy vydávající se za obživou. MZA Brno, F 281 Velkostatek Uherský Brod, kart. 171, inv. č. 606, fol. 2, 3. 
I v tomto případě se objevuje korespondence psaná na celou šíri stránky, byt pochází od instančně podřízeného původce a mohlo by se očekávat, že bude psána jen na polovinu. Oslovení úřadu zůstává stejné, ale obsahově se nejedná o korespondenci z vlastní iniciativy, ale o reakce na konkrétní vyhlášky/požadavky krajského úřadu. ${ }^{16}$

Korespondence od krajského úřadu se ve fondech velkostatků nachází většinou v opisech. V levém horním rohu bylo obdobně, jako je tomu u korespondence od ústředního orgánu majitele panství, napsáno, odkud je předpis odeslán, Von Kaiserliche Königliche Kreisamte,${ }^{17}$ psalo se na celou šíríi stránky, text končil datem, podpisem krajského úředníka, pod kterým se v levém rohu ještě nacházela vnitřní adresa, pro který úřad je nařízení určeno.

Korespondence přijatá od zemského gubernia má stejnou formu jako ta zaslaná od krajského úřadu. ${ }^{18}$

\section{Majitel panství}

Korespondence adresovaná majiteli panství se v archivech velkostatků dá najít dvojí, a to jednak písemnosti zaslané majiteli vrchním úřadem (Oberamt), jednak poddanými, resp. jejich zástupci z obcí. Oberamt majiteli psal ve vlastních věcech, současně však zastupoval i poddané, a to obvykle $\mathrm{v}$ těch záležitostech, které nemohl sám rozhodnout. ${ }^{19}$ Existují však případy, kdy majiteli panství psaly obce, resp. jejich zástupci, a Oberamt z této komunikace vynechávají. ${ }^{20}$

Běžnou podobou komunikační písemnosti z vrchního úřadu panství adresované majiteli panství byly hlášení a zprávy. Jejich text začínal intitulací majitele, která byla psána větším ozdobným písmem a odsazená od druhého oslovení. Šlo o varianty Hochgebornen nebo Euer Durchlauchtigster [titul] (prinz, reichsfürst...), Gnädigster Herr Herr! ${ }^{21}$ Po příslušné mezeře za intitulací následuje text ve smyslu ponížené žádosti, se kterou se pisatel na majitele panství obrací. Pokud je majitel panství nadále oslovován, je i toto psáno větším písmem oproti ostatnímu textu, a to ve formě Euer [titul] (hochfürstlichen) Durchlaucht. Podpisu v některých případech předchází i předpodpisová kurtoazie, která je připojena na konci sdělení, před datací a podpisem odesílajícího, a bývá psána větším ozdobným písmem a zní např. Euer Königliche Hoheit nebo Euer Hochfürslichen Durchlaucht ${ }^{22}$. Z vnější strany je napsána adresa, kdo je odesílatelem a krátké podání,

16 MZA Brno, F 104 Velkostatek Židlochovice, kart. 620, fasc. 435, fol. 68.

17 MZA Brno, F 104 Velkostatek Židlochovice, kart. 620, fol. 66.

18 Tamtéž, fol. 35 .

19 Jedním z příkladů může být žádost romské rodiny z panství Uherský Brod o povolení k přestěhování. MZA Brno, F 281 Velkostatek Uherský Brod, kart. 94, sg. 36/5, inv. č. 540, fol. 54, 55.

20 V případě velkostatku Veveří je toto jednání zcela pochopitelné, nebot se jednalo o stížnost na odvod vysokých deputátních dávek nařízených vrchním úřadem a poddaní žádají, aby se jich majitel zastal. MZA Brno, F 219 Velkostatek Veveří, inv. č. 121, evid. č. 103, fol. 7.

21 Např. MZA Brno, G 436 Rodinný archiv Kouniců, kart. 666, inv. č. 5676, fol. 15.

22 Např. MZA Brno, G 436 Rodinný archiv Kouniců, kart. 666, inv. č. 5676, fol. 78. 
čeho se žádost týká. Majitel panství své poznámky k žádosti připojoval přímo k textu anebo „vzhůru nohama“ k rubru napsal svou rezoluci. Tato korespondence byla ve většině př́ípadů vedena na kolkovaném papíře.

Další z variant korespondence pro majitele panství byly pravidelné hospodářské zprávy, obdobné jako dostával i ústřední orgán majitele panství. Intitulace i přepodpisová kurtoazie se zde objevují ve stejné formě jako bylo zmíněno výše. Pod datem a místem vydání se podepsal úředník příslušného úřadu nebo jsou podepsáni všichni úředníci, v případě, že šlo o hromadné hlášení. ${ }^{23}$

Korespondence, kterou kancelář panství obdržela od majitele panství, byla psána jako nařízení, na celou šíri stránky. Vrchní úřad byl oslovován jako Löbliches Oberamt nebo nařízení začínalo nadpisem, oč se jedná - instrukce, předpis apod. To bylo napsáno větším a ozdobnějším písmem než ostatní text, a pod takovým nadpisem bylo uvedeno, kterým úřadům je nařízení adresováno. Jejich zástupci převzetí podepisovali potom, co se s ním seznámili, opět slovesy (vor)gelesen anebo erhalten. Pokud byly určeny všem úředníkům, podepisovali je všichni. ${ }^{24}$ Předpisy byly podepisovány majitelem panství nebo jeho zástupcem. ${ }^{25}$ Tato skupina se podle svých vnějších znaků i podle obsahu dá rozdělit na dvě samostatné části, kdy jednou jsou písemnosti administrativního charakteru a druhou ty, co mají povahu normativní.

Předpokládá se, že osobní oslovování úřednictva spadá spíše do dob starších a v době konce 18. a následujícího 19. století se jedná o přežitek, ale přesto se lze setkat na tuto dobu až s familiárním oslovením Lieber Oberamtmann und liebe Beamten! ${ }^{26}$ Kdy jsou tedy osloveni přímo úředníci namísto neosobního oslovení úřadu (Löbliches Oberamt).

\section{Ústřední orgán majitele panství}

Bylo-li panství začleněno do systému ústřední správy dominia jednoho majitele, bylo pak takové správě podřízeno a vrchní úředník neboli oberamtman, jako zástupce panství, musel s touto nadřízenou institucí komunikovat, posílat jí rozličná hlášení a zprávy.

Ústřední orgán majitele panství byl nazýván několika různými způsoby, jako vrchní administrace, inspekce nebo ředitelství, což se odráží v intitulaci zpráv a hlášení, která jí byla zasílána. Podle toho se pak objevuje oslovení jako Löbliche Inspektorat, ${ }^{27}$ Löbliche Direction, ${ }^{28}$ Hohe Herrschafts Administration!, Hohe Güterinspektion!, ${ }^{29}$ Löbliche Hohe Güter

23 MZA Brno, G 436 Rodinný archiv Kouniců, kart. 666, inv. č. 5676, fol. 1-5.

24 MZA Brno, F 281 Velkostatek Uherský Brod, kart. 94, inv.č. 540, fol. 2, 3.

25 Nařízení s layoutem zprávy zasílá např. sekretář hraběte Kounice v jeho nepř́ítomnosti úředníků v Uherském Brodě. MZA Brno, F 281 Velkostatek Uherský Brod, kart. 94, inv. č. 540, fol. 499.

26 Tamtéž, fol. 52.

27 MZA Brno, F 200 Velkostatek Třebíč, kart. 1107, fol. 44.

28 Tamtéž, fol. 45.

29 MZA Brno, F 219 Velkostatek Veveří, kart. 95, inv. č. 111, fol. 606. 
Oberdirection ${ }^{30}$ a další obdobné variace. Ani tato hlášení a zprávy neměly jednotnou formu a podle účelu se objevuje několik jejich podob.

$\mathrm{V}$ případech, kdy se jednalo o zprávu o hospodaření jednotlivých úřadů na panství, byl text psán na pravou stranu do sloupce. Často se objevuje jen odkaz na událost uvedenou v denních záznamech. Obsahově se jednalo především o stav finančního hospodaření jednotlivých úřadů, odhad výnosů nebo rozpočet na další rok.

Kromě zpráv a hlášení byly ústřednímu orgánu majitele panství zasílány výkazy robot ze statků patřících do správy panství nebo vyúčtování hospodaření jednotlivých úřadů, oboje především ve formě tabel, kde byly uvedené př́ijmy i výdaje, a na konci pod datací byl připojen podpis příslušného úředníka. Tabely byly nadepsány názvem úřadu, ze kterého vyúčtování šlo. ${ }^{31} \mathrm{Na}$ konci 18. století (1789) byla vydána kniha předpisů, jak mají vyúčtování příjmů a výdajů všech hospodářských úřadů vypadat. ${ }^{32}$

Krom hlášení, která měla předpokládaný layout zprávy, se objevuje i korespondence, která byla psána na celou šíŕi stránky. Obsahově se stále jedná o provozní hospodářské záležitosti, které jsou však obchodního a smluvního charakteru.

Panství začleněné do systému ústřední správy nejenže muselo ústřední orgán majitele panství informovat o finančním hospodaření úřadů na něm zastoupených, ale také bylo příjemcem nařízení a rozkazů vydaných tímto ústředním orgánem majitele panství, často přeposílaných od majitele dominia.

V případě nařízení zaslaných od ústředního orgánu majitele panství oslovení nebo intitulace vrchního úřadu chybí. V levém horním rohu byl uveden původce, obvykle ve tvaru Von der Inspection ${ }^{33}$ nebo jiné označení ústředního orgánu majitele panství, např. fürstliche Güter Oberdirektion. ${ }^{34}$ Následovala mezera a za ní na celou říši stránky psané nařízení. Na konci bylo datum, místo vydání a podpis oberdirectora, ovšem ne vždy s uvedenou funkcí. Přijetí, pokud nešlo o obecné nařízení, potvrzoval vrchní úředník, případně některý z dalších úředníků panství, kterého se nařízení týkalo, svým podpisem, datem a slovesem (vor)gelesen, erhlaten. ${ }^{35} \mathrm{Na}$ konci strany, kde je podpis představeného úředníka ústřední správy, je uvedena vnitřní adresa.

\section{Vrchní úrady jiných panství}

Korespondence s vrchními úřady jiných panství by se dle literatury měla nazývat nóty. Jak ale bylo zmíněno na začátku, je toto označení zavádějící a název nóty by bylo vhodné vyhradit pro písemnosti tako označené.

30 MZA Brno, F 281 Velkostatek Uherský Brod, kart. 121, inv. č. 582, fol. 192.

31 Např. MZA Brno, F 281 Velkostatek Uherský Brod, kart. 121, inv. č. 582, fol. 2-4.

32 MZA Brno, B 17 Moravské místodržitelství - patenty, sg. J37.

33 MZA Brno, F 219 Velkostatek Veveří, kart. 95, inv. č. 111, fol. 529. Inspektor Köller, který podepisuje nařízení adresovaná veverskému velkostatku byl zároveň inspektorem i pro kounicovský Uherský Brod, kde zřejmě v nedalekých Kvasicích pobýval, nebot část nařízení je odesíláno právě odtamtud. 
Adresát byl oslovován jako Löbliches Oberamt! ${ }^{36}$, oslovení bylo psáno větším písmem a odděleno mezerou od dalšího textu. Psalo se na celou šíŕi stránky a komunikace probíhala v němčině. Týkala se především společných správních nebo hospodářských záležitostí, ale často se řešily i sporné záležitosti, jako byly hranice panství.

I zde se však dá nalézt korespondence, která svým rozložením neodpovídá tomu, jak literatura označuje layout pro písemnosti souřadných úřadů. Jako příklad se dá uvést komunikace mezi panstvími Veveří a Uherským Brodem. Na dotaz veverských úředníků, zda Uherskému Brodu nechybí cikán (Rom) Zelinka, odpovídá oberamt uherskobrodského panství písemností ve formě zprávy, že jim Zelinka nechybí, poněvadž jim nepatří. ${ }^{37}$

\section{Ostatní úřady zastoupené na panství}

Korespondence od podřízených úřadů k oberamtu měla jednotnou podobu zprávy. List byl na polovinu přeložen, psalo se do pravého sloupce. Oslovení Löbliches Oberamt! ${ }^{38}$ bylo napsáno větším písmem, odděleno mezerou od ostatního textu, který byl na konci podepsán úředníkem, který zprávu posílal. Jinou variantou pak byla periodická hlášení o hospodaření jednotlivých úřadů, ${ }^{39}$ ke kterým se vrchní úředník vyjadřoval přímo do podání a která byla nadepsána právě informací, o jaké hlášení a z jakého úřadu se jedná.

Komunikace s úřady podřízenými úřadu vrchnímu probíhala formou nařízení nebo poněkud překvapivě také formou zpráv, kdy tedy bylo psáno na pravou polovinu přeloženého listu. Oslovení či intitulace chybí. V prvním řádku byla vnitřní adresa, nejčastěji ve tvaru Vom (fürstliche) oberamte. An das [název úřadu] nebo bylo pořadí prohozeno, Dem Steueramte, vom oberamte. Zpráva končila podpisem vrchního úředníka. V některých případech úředník, kterému byla zpráva adresována, potvrzoval její přijetí podpisem a slovesem erhalten, (vor)gelesen. ${ }^{40}$

Komunikace jednotlivých úřadi̊, které byly na panstvích zastoupeny a podřízeny Oberamtu, mezi sebou navzájem se v archivech velkostatků nenalézá. Zdá se, že pokud neprobíhala komunikace ústně, řešila se přes vrchní úřad. V jednom z těchto případů lesní úřad velkostatku Veveří uctivě žádá vrchní úřad, zda by mohl zakázat ovčáckému čeledínovi pást ovce v oboře kolem hájenky, nebot̉ to ruší mladé bažanty při sezení na vejcích a ti mohou opustit hnízdo, protože mají neustále strach. ${ }^{41}$

\footnotetext{
36 Tamtéž, fol. 161.

37 Tamtéž, kart.171, 606, fol. 322.

38 MZA Brno, F 200 Velkostatek Třebíč, kart. 1071, fol. 139.

39 MZA Brno, F 219 Velkostatek Veveř́í, kart. 99, inv. č. 117, fol. 1.

40 MZA Brno, F 219 Velkostatek Veveří, kart. 103, inv. č. 121, fol. 93.

41 MZA Brno, F 219 Velkostatek Veveří, inv. č. 117, evid. č. 99, fol. 491.
} 


\section{Obce na panství}

Komunikace s obcemi na panství, případně s poddanými, je svým provedením podobná té, kterou vrchní úřad posílal podřízeným úřadům, alespoň co se layoutu týká. Ale objevují se tu i česky psané texty. Šlo o různá sdělení nebo třeba potvrzení, psány byly na celou šíři stránky i na její polovinu. Německy psané se týkaly především gruntovních záležitostí, byly posílány na kolkovaném papíře, měly adresu a rubrum z vnější strany. Všechny jsou podepisovány vrchním úředníkem. V levém horním rohu bylo uvedeno $A n$ der [jméno adresáta], vpravo pak Vom Oberamte, bez nějaké větší mezery začínal vlastní text.

Písemná komunikace přišlá k Oberamtu od poddaných či obcí spadajících pod správu panství měla stejnou intitulaci, jako tomu bylo v předchozím případě, avšak byly psány na celou šíri stránky. Pro ně platilo, že pokud byla žádost psaná v českém jazyce, bylo na ně i v českém jazyce odpovídáno. V takovém případě byl úřad oslovován jako Slawný wrchni auřad. ${ }^{42}$

\section{Závěr}

Na základě prostudovaných pramenů se situace na jednotlivých panstvích dá spíše srovnat než jakkoliv zobecnit. Předpokládaná unifikace komunikačních písemností na zkoumaných panstvích rámcově odpovídá v úvodu uvedeným předpokladům, má však také svá specifika, nebot' ke změnám v písemné komunikaci docházelo postupně.

Úředním jazykem je téměř bezvýhradně němčina. Na kolik se dá považovat komunikace majitele přímo s poddanými za úřední komunikaci, je sporné a nezobecnitelné. Záleží na konkrétních případech a dochování v registraturních pomůckách.

Nelze se domnívat, že komunikace mezi jednotlivými úřady probíhala automaticky podle stanovených pravidel. Je nezbytné se zabývat obsahem a nehledět pouze na formu a layout. Navzdory předpokladům se stále majitel panství Uherský Brod obrací k úředníkům milým oslovením, místo neosobního oslovení úřadu. Což být může v tomto případě dáno i jistou tradicí, kdy uherskobrodské panství bylo tradičním kounicovským panstvím, kdežto např́íklad u Veveří se majitelé často střídali. V případě komunikace vrchního úřadu s úřady podřízenými byla sice použila nařízení, ale svým layoutem odpovídala provedení pro zprávu. Ani komunikace mezi oberamty těchto dvou panství neprobíhala standardně dle očekávání. Naopak nařízení přijatá od krajských úřadů mají jednotnou formu.

Osvětlení zmíněných specifik bude možné až na základě hlubší analýzy komunikačních písemností v delším časovém horizontu, zejména pak ve srovnání s písemnou agendou předtereziánského období.

42 MZA Brno, F 281 Velkostatek Uherský Brod, kart. 16, inv, č. 477, fol. 10. 


\section{Communication Papers of Moravian Estates. Case Analysis Example of Communication of Estates Třebíč, Uherský Brod, Veveři and Židlo- chovice at the End of the 18th and the Beginning of the 19th Century.}

The Study brigs a fist insight into huge source material, which deserves more extensive research. In summary, the anticipated unification of communication papers in the post-Theresian period for the estates in the study generally corresponds to the assumptions referred to in the introduction, but there are certain specific features. It cannot be assumed that communication between the individual authorities took place automatically on the basis of established rules. It is necessary to address the content and not just look at the form and layout. In spite of the assumptions, the owner of the estates in Uherský Brod addresses officials with a familiar address, not an impersonal official address. In this case, it may be due to a certain tradition, since the Uherský Brod estate was a traditional Kounic estate, while, for example, in the case of Veveří, the owners often changed. As regards communication between high authorities and subordinate authorities, the regulations were adhered to, but their layout corresponded to the design for reports. Even communication between the administrative units of these two large estates did not proceed in the standard and expected way. In contrast, regulations adopted from regional authorities had a uniform form. Further elucidation of the above-mentioned specifics will be only possible with a deeper analysis of communication papers over a longer time horizon, particularly in comparison with the written agenda of the pre-Theresian period. 
